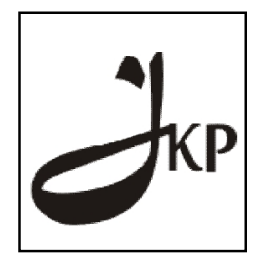

Jurnal Konseling dan Pendidikan

ISSN Cetak: 2337-6740 - ISSN Online: 2337-6880

http://jurnal.konselingindonesia.com

Volume 3 Nomor 3, November 2015, HIm 1-7

Info Artikel:

Diterima 02/10/2015

Direvisi 04/11/2015

Dipublikasikan 28/11/2015

\title{
Pengaruh Layanan Bimbingan Kelompok Terhadap Kemandirian Dalam Menyelesaikan Masalah Belajar
}

\section{Azmatul Khairiah Sari}

\section{Abstract}

This article discusses about autonomy to solve their learning problem. The students need a autonomy to solve their learning problem. Group guidance can be used to improve autonomy to complete the learning problem. This research was aimed at disclosing the influence of group guidance service to improve autonomy to solve the learning problem. An experimental research pretest and posttest control group design was utilized to test whether group guidance can better improve autonomy to complete the learning problem. The findings of this research were: (1) there is a significant difference between post test and pretest of the experiment group on autonomy to complete the learning problem. (2) there is no difference on the pre and post test of the control group students on autonomy to complete the learning problem. (3) there is a significant difference on autonomy to complete the learning problem between experiment group and control group.

Keyword: Bimbingan kelompok, Kemandirian, Masalah belajar

Copyright (C) 2015 IICET (Padang - Indonesia) - All Rights Reserved

Indonesian Institute for Counseling, Education and Theraphy (IICET)

\section{PENDAHULUAN}

Inti dari pendidikan adalah belajar. Tidak ada pendidikan tanpa kegiatan belajar. Peserta didik melakukan kegiatan belajar sehingga dirinya berada dalam suasana belajar dan pendidik menyelenggarakan proses pembelajaran. Pendidikan merupakan kegiatan pembelajaran sepanjang hayat untuk mengembangkan potensi peserta didik ke tingkat yang optimal sampai hasilnya terefleksikan dalam keseharian mereka.

Islam juga menganggap penting tentang belajar. Wahyu pertama mengenai belajar, ini terdapat dalam surat Al-'alaq ayat 1-5 yang artinya sebagai berikut:

Bacalah dengan (menyebut) nama Tuhanmu yang menciptakan (1) Dia telah menciptakan manusia dari segumpal darah (2) Bacalah, dan Tuhanmulah yang Maha Pemurah (3) Yang mengajar (manusia) dengan perantaran kalam (4) Dia mengajar kepada manusia apa yang tidak diketahuinya. (5) (QS 96:15 ).

Maksudnya, bahwa perintah Allah yang pertama kepada Rasulullah adalah membaca. Rasulullah yang awalnya tidak pandai membaca kemudian belajar membaca wahyu yang telah datang kepada beliau. Jadi belajar adalah kunci untuk menggapai ilmu pengetahuan. Sasaran belajar diarahkan pada ranah kognitif, afektif dan psikomotorik. Pelaksanaan belajar ini dapat dibimbing oleh seorang guru. Salah satu guru yang melaksanakan pelaksanaan pembelajaran adalah guru bimbingan dan konseling atau konselor. Ketentuan mengenai konselor atau guru bimbingan dan konseling sebagai salah satu pelaksana pembelajaran adalah UU No. 20/2003 tentang sistem pendidikan nasional pasal 1 butir 1 dan pasal 1 butir 6 .

Ketentuan dalam Undang-Undang No.20/2003 tentang sistem pendidikan nasional memberikan nuansa baru tentang pengertian pendidikan dan secara eksplisit menyebutkan konselor sebagai pendidik. Ketentuan mengenai konselor atau guru bimbingan dan konseling sebagai salah satu pelaksana pembelajaran adalah UU No. 20/2003 tentang sistem pendidikan nasional pasal 1 butir 1 dan pasal 1 butir 6 . Ketentuan tersebut berbunyi sebagai berikut:

Pasal 1 butir 1 :

Pendidikan adalah usaha sadar dan terencana untuk mewujudkan suasana belajar dan pembelajaran agar peserta didik secara aktif mengembangkan potensi dirinya untuk memiliki kekuatan spiritual keagamaan, 
pengendalian diri, kepribadian, kecerdasan, akhlak mulia, dan keterampilan yang diperlukan dirinya, masyarakat, bangsa dan negara.

Pasal 1 Butir 6 yang mengemukakan bahwa konselor adalah pendidik:

Pendidik adalah tenaga kependidikan yang berkualifikasi sebagai guru, dosen, konselor, pamong belajar, widiaswara, tutor, instruktur, fasilitator, dan sebutan lain yang sesuai dengan kekhususannya, serta berpartisipasi dalam menyelenggarakan pendidikan.

Belajar bertujuan untuk mengembangkan potensi yang ada pada peserta didik. Apabila potensi yang ada pada peserta didik tidak dapat dikembangkan sebagaimana harusnya maka potensi tersebut akan terpendam. Pengembangan kemampuan dan potensi peserta didik bisa dilakukan dalam layanan bimbingan konseling. Layanan bimbingan konseling menurut Prayitno (2004: 114) bertujuan:

Membantu individu untuk menjadi insan yang berguna dalam kehidupannya yang memiliki berbagai wawasan, pandangan, interpretasi, pilihan, penyesuaian dan keterampilan yang berkenaan dengan diri sendiri dan lingkungan. Insan seperti itu adalah insan yang mandiri yang memiliki kemampuan untuk untuk memahami diri sendiri dan lingkungannya secara tepat dan objektif, menerima diri sendiri dan lingkungan secara positif dan dinamis, mampu mengambil keputusan secara tepat dan bijaksana, mengarahkan diri sendiri sesuai keputusan yang diambilnya itu sehingga mampu mewujudkan diri sendiri secara optimal.

Pelaksanaan pembelajaran dilakukan di lembaga pendidikan formal. Salah satu lembaga formal adalah SLTP/SMP. Guru bimbingan dan konseling menjadi salah satu bagian untuk membimbing siswanya mencapai tujuan KTSP di SLTP. Ketentuan beban kerja guru bimbingan dan konseling telah ditetapkan dalam PP No. 74/2008 pasal 54 butir 6. Selain itu ada juga Permenpan No.16/2009 pasal 5 ayat 3, tentang jabatan fungsional guru dan angka kreditnya, bahwa guru bimbingan dan konseling mengampu paling sedikit 150 siswa dalam satu tahun.

Konselor dapat melaksanakan layanan bimbingan dan konseling adalah orang yang memang ahli di bidannya. Menurut Gladding (dalam Lesmana, 2005:46) faktor inisiatif klien, kualitas klien dan kualitas konselor merupakan beberapa faktor yang mempengaruhi proses konseling. Jadi dalam pelaksanaan bimbingan dan konseling, ada tiga hal yang mempengaruhi keberhasilannya. Salah satunya adalah kualitas konselor. Konselor yang memang telah sesuai dengan aturan Permendiknas no.27 tahun 2008 diharapkan memiliki kualitas dalam pelaksanaan bimbingan dan konseling.

Konselor akan melaksanakan beberapa layanan bimbingan dan konseling, salah satunya adalah layanan bimbingan kelompok. Menurut Romlah (2001: 3) layanan bimbingan kelompok adalah salah satu teknik bimbingan yang berusaha membantu individu agar dapat mencapai perkembangannya secara optimal sesuai dengan kemampuan, bakat, minat, serta nilai-nilai yang dianutnya dan dilaksanakan dalam situasi kelompok.

Layanan bimbingan kelompok merupakan salah satu layanan dalam bimbingan dan konseling yang bertujuan untuk mengembangkan kemampuan bersosialisasi dan berkomunikasi siswa sebagai peserta layanan. Kegiatan layanan bimbingan kelompok mengaktifkan dinamika kelompok untuk membahas berbagai hal yang berguna bagi pengembangan pribadi dan/atau pemecahan masalah individu yang menjadi peserta kelompok (Prayitno. 2012: 149).

Prayitno (1997: 99), layanan bimbingan kelompok dimaksudkan untuk memungkinkan siswa secara bersama-sama memperoleh berbagai bahan dari narasumber terutama guru pembimbing yang bermanfaat untuk kehidupan sehari-hari baik sebagai individu maupun sebagai pelajar, anggota keluarga, dan masyarakat. Dalam layanan bimbingan kelompok para siswa dapat diajak bersama-sama mengemukakan pendapat tentang sesuatu dan membicarakan topik-topik penting, mengembangkan nilai-nilai tentang hal tersebut dan mengembangkan langkah-langkah bersama untuk menangani permasalahan yang dibahas di dalam kelompok. Selain itu Ohlsen (1977: 21) menyatakan bahwa dalam kelompok, individu belajar untuk membantu orang lain dan menerima bantuan mereka dan belajar berbicara secara terbuka tentang diri mereka sendiri dan menaklukkan kekurangan mereka.

Dalam bimbingan kelompok juga membahas bagaimana peserta didik dapat membahas suatu topik untuk menyelesaikan masalahnya. Diistilahkan dengan homogenitas dalam kelompok. Prayitno (2004: 310) 
menyebutkan bahwa adanya homogenitas dalam kelompok yaitu (1) bimbingan kelompok para anggota kelompok homogeny (yaitu siswa satu kelas atau satu tingkat yang sama), (2) "masalah" yang dialami oleh semua anggota adalah sama, yaitu memerlukan informasi yang diberikan itu, (3) tindak lanjut dari diterimanya informasi itu juga sama, yaitu untuk untuk menyusun rencana dan membuat keputusan, (4) reaksi atau kegiatan yang dilakukan oleh para anggota dalam proses pemberian informasi secara relatif sama. Ciri homogenitas inilah yang menandai layanan bimbingan kelompok berbeda dengan konseling kelompok. Masalah yang umum dihadapi peserta didik adalah masalah belajarnya.

Prayitno, dkk (1997) mengatakan bahwa masalah belajar adalah masalah khusus yang berkaitan dengan upaya penyelenggaraan kegiatan belajaar di dalam dan di luar kelas yang tergantung pada lima hal yakni : prasyarat penguasaan materi pelajaran (P), keterampilan belajar (T), sarana belajar (S), keadaan diri pribadi (D), dan lingkungan belajar dan sosio emosional (L). Apabila siswa memiliki masalah belajar yang tinggi maka siswa akan susah mencapai tujuan pembelajaran. Peserta didik diharapkan memiliki kemandirian dalam menyelesaikan masalah belajarnya agar tujuan pembelajaran dapat dicapainya.

Prayitno (2009: 26), menyatakan bahwa kemandirian merupakan kondisi pribadi yang telah mampu memperkembangkan pancadaya kemanusiaan bagi tegaknya hakikat manusia pada dirinya sendiri dalam bingkai dimensi kemanusiaan. Untuk dapat menjadi mandiri maka seseorang perlu:

(1) Memahami dan menerima diri sendiri secara objektif, positif, dan dinamis (2) Memahami dan menerima lingkungan secara objektif, positif dan dinamis, (3) Mampu mengambil keputusan, (4) Mengarahkan diri sendiri, dan (5) Mewujudkan diri sendiri. (Prayitno: 2009: 26).

Peserta didik yang memiliki kemandirian dalam menyelesaikan masalah belajarnya diperkirakan akan tinggi tingkat keberhasilan belajarnya. Namun kebanyakan peserta didik tidak mempedulikan masalah belajar yang dimiliknya dan membiarkan begitu saja masalah belajarnya. Masalah belajar yang dibiarkan begitu saja akan membuat peserta didik tidak memiliki kemandirian dalam menyelesaikan masalah belajarnya.

Menurut Mohammad Ali (2008: 118) ada beberapa faktor yang mempengaruhi kemandirian, yaitu: gen atau keturunan orang tua, (2) pola asuh orang tua, (3) sistem pendidikan di sekolah, (4) sistem kehidupan di masyarakat. Jadi kemandirian dalam menyelesaikan masalah belajar salah satunya dapat ditingkatkan dengan memberikan pembiasaan dan pengetahuan tentang kemandirian tersebut kepada siswa. Guru bimbingan dan konseling di lingkungan sekolah dapat meningkatkan kemandirian siswa dalam menyelesaikan masalah belajarnya melalui layanan bimbingan kelompok.

Berpijak dari latar belakang di atas, maka penelitian ini bertujuan memberikan layanan kepada peserta didik agar ia bisa meningkatkan kemandirian dalam menyelesaikan masalah belajar tersebut.

Dengan melaksanakan layanan bimbingan kelompok, diduga akan dapat membantu siswa untuk meningkatkan kemandirian dalam menyelesaikan masalah belajarnya dengan bantuan teman sesama anggota bimbingan kelompoknya. Dugaan tersebut perlu dibuktikan melalui eksperimen.

Penelitian ini bertujuan untuk menjelaskan: (a) perbedaan antara kemandirian dalam menyelesaikan masalah belajar siswa kelompok eksperimen sebelum dan sesudah mendapatkan layanan bimbingan kelompok, (b) perbedaan antara kemandirian dalam menyelesaikan masalah belajar siswa kelompok kontrol sebelum dan sesudah mendapat layanan bimbingan dan konseling pada umumnya, (c) perbedaan antara kemandirian dalam menyelesaikan masalah belajar siswa kelompok eksperimen dan kontrol sesudah layanan bimbingan kelompok.

\section{METODELOGI PENELITIAN}

Penelitian ini dilakukan dengan menggunakan pendekatan penelitian kuantitatif dengan rancangan eksperimen, menggunakan desain tes awal, tes akhir, dan kelompok kontrol. Kelompok eksperimen diberi perlakuan dengan bimbingan kelompok topik tugas kemandirian dalam menyelesaikan masalah belajar, sedangkan pada kelompok kontrol tidak diberi perlakuan layanan bimbingan kelompok, dan kedua kelompok itu mengisi tes awal dan akhir. Populasi dalam penelitian ini adalah siswa kelas VII SMP N 13 Padang. Teknik pengambilan sampel yang digunakan dalam penelitian ini adalah teknik non random sampling, yaitu dengan metode sampling purposif (purposive sampling). Sampel untuk kelompok eksperimen berjumlah 11 orang dan sampel kelompok kontrol juga 11 orang. Pengumpulan data dilakukan dengan menggunakan angket oleh peneliti dibantu oleh guru Bimbingan dan Konseling. Pengerjaan pretest dan posttest dilakukan secara serempak oleh siswa dan tidak boleh dibawa pulang untuk menjamin keabsahan dan keakuratan data. Teknik analisis data menggunakan Wilcoxon 
Signed Rank Test dan Kolmogorov-Smirnov Dua Sampel dengan menggunakan jasa komputer program SPSS versi 15,00 .

HASIL DAN PEMBAHASAN PENELITIAN

Pengaruh Layanan Bimbingan Kelompok Terhadap Kelompok Eksperimen Tentang Kemandirian Dalam Menyelesaikan Masalah Belajar

Pengujian hipotesis pertama yang dilakukan dengan teknik analisis statistik Wicoxon's Signed Ranks Test melalui program komputer SPSS versi 15.0 Didapatkan hasil perhitungan seperti yang terangkum pada tabel 1 berikut ini.

Tabel 1 : Hasil Analisis Wicoxon's Signed Ranks Test : Perbedaan Kemandirian Dalam Menyelesaikan Masalah Belajar Pada Pretest dan Posttest Kelompok Eksperimen

Test Statistics(b)

\begin{tabular}{lr}
\hline & \multicolumn{2}{c}{ Posttest-Pretest } \\
\hline$Z$ & $-2,936(a)$ \\
$\begin{array}{l}\text { Asymp. Sig. (2- } \\
\text { tailed) }\end{array}$ &, 003 \\
\hline a Based on negative ranks. & \\
b Wilcoxon Signed Ranks Test &
\end{tabular}

Berdasarkan tabel 1 di atas di atas, terlihat bahwa angka probabilitas Asmyp. Sig.(2-tailed) kemandirian dalam menyelesaikan masalah belajar kelompok eksperimen sebesar 0,003 , atau probabilitas di bawah alpha 0,05 $(0,003<0,05)$. Dari hasil tersebut maka Ho ditolak dan $\mathrm{H}_{\mathrm{I}}$ diterima. Dengan demikian maka hipotesis pertama yang diuji dalam penelitian ini dapat diterima, yaitu "Terdapat perbedaan yang signifikan pada kemandirian dalam menyelesaikan masalah belajar siswa kelompok eksperimen sebelum (pretest) dan setelah diberikan perlakuan layanan bimbingan kelompok (posttest)".

Berdasarkan hasil penelitian yang dilakukan melalui eksperimen dengan topik tugas tentang kemandirian dalam menyelesaikan masalah belajar, ternyata kemandirian siswa kelompok eksperimen secara keseluruhan menunjukkan adanya perbedaan secara signifikan antara sebelum dan sesudah mengikuti layanan bimbingan kelompok. Hal tersebut berarti adanya pengaruh kegiatan layanan bimbingan kelompok terhadap kemandirian dalam menyelesaikan masalah belajar.

Melalui layanan bimbingan kelompok, siswa bisa merasakan bebasnya menyampaikan pendapat, dapat mengembangkan perasaan, pikiran, persepsi, wawasan dan sikap yang menunjang tingkah laku untuk mengendalikan diri, tenggang rasa, dan sumbang saran kepada sesama anggota kelompok. Melalui bimbingan kelompok anggota bisa mendapatkan informasi-informasi akurat yang dapat membantu anggota kelompok membuat perencanaan dan keputusan hidup yang tepat (Robert L. Gibson dan Marianne H. Mitchell, 2011: 275). Layanan bimbingan kelompok memberikan informasi kepada para anggota kelompok untuk membuat tindak lanjut atau keputusan yang tepat untuk menyelesaikan masalah belajar yang dihadapinya.

Layanan bimbingan kelompok secara nyata menyebabkan seseorang untuk melakukan serangkaian kegiatan yang mengarah kepada ketercapaian tujuan tertentu, terutama dalam mencapai sukses belajar.

Menurut peneliti, hal-hal yang cukup menarik dalam bimbingan kelompok adalah dinamika kelompok dimana setiap anggota kelompok merasa dirinya dihargai, diberikan kesempatan seluas-luasnya menyatakan pendapatnya, diajarkan untuk saling berbagi yakni mendengarkan pendapat orang lain, adanya game yang cukup mengundang suasana riang namun sportivitas tetap terjaga, apalagi nuansa pemimpin kelompok yang selalu memberikan motivasi dan selalu menekankan azaz-azaz dalam bimbingan kelompok. Hal tersebut mendorong para anggota kelompok untuk berpartisipasi.

Salah satu yang menjadikan siswa sebagai anggota kelompok eksperimen memiliki kemandirian dalam menyelesaikan masalah belajar melalui layanan bimbingan kelompok, adalah materi-materi yang berkenaan dengan kemandirian dan motivasi yang diberikan konselor kepada siswa. Selain itu konselor memanfaatkan dinamika kelompok agar siswa dapat aktif dalam bimbingan kelompok tersebut. Melalui dinamika kelompok 
setiap bahasan didiskusikan dari sisi apa yang terjadi (realita kehidupan), mengapa topik itu terjadi (diagnosis), kalau berkelanjutan hendaknya apa yang bakal terjadi (prognosis), dan upaya apa yang akan dilakukan sebagai solusi dalam topik tersebut (Prayitno: 1995). Pada akhir diskusi masing-masing anggota kelompok memberikan pernyataan apa yang akan dilakukan setelah kegiatan bimbingan kelompok berakhir.

Keaktifan siswa pada pertemuan pertama belum begitu terasa. Maka dibutuhkan ice breaking atau mencairkan suasana yang beku dan canggung antara siswa. Ini bisa dilakukan dengan permainan yang berkenaan dengan topik yang dibahas, memotivasi siswa bahwa dalam layanan bimbingan kelompok tidak sama dengan cara belajar di kelas. Pada akhirnya, pertemuan selanjutnya siswa bisa merasa aktif dan berpartisipasi dalam memberikan pendapat mengenai topik yang dibahas tersebut.

Pengaruh Layanan Bimbingan Kelompok Terhadap Kelompok Kontrol Tentang Kemandirian Dalam Menyelesaikan Masalah Belajar

Hipotesis kedua penelitian ini juga diuji menggunakan analisis ststistik dengan teknik Wicoxon's Signed Ranks Test dengan program SPSS versi 15.0. Adapun hasil perhitungan terangkum pada tabel 2 berikut.

Tabel 2

Hasil Analisis Wicoxon's Signed Ranks Test : Perbedaan Kemandirian Dalam Menyelesaikan Masalah Belajar Pada Pretest dan Posttest Kelompok Kontrol

\begin{tabular}{lr}
\hline & \multicolumn{2}{c}{ Postest-Preetest } \\
\hline $\mathrm{Z}$ &,$- 806(\mathrm{a})$ \\
$\begin{array}{l}\text { Asymp. Sig. (2- } \\
\text { tailed) }\end{array}$ &, 420 \\
\hline
\end{tabular}

a Based on negative ranks.

b Wilcoxon Signed Ranks Test

Dari tabel 2 di atas di atas, terlihat bahwa angka probabilitas Asmyp. Sig.(2-tailed) kemandirian dalam menyelesaikan masalah belajar kelompok kontrol sebesar 0,420, atau probabilitas di atas alpha 0,05 $(0,420>$ 0,05). Dari hasil tersebut maka Ho ditolak dan $\mathrm{H}_{\mathrm{I}}$ diterima. Dengan demikian maka hipotesis kedua yang diuji dalam penelitian ini dapat diterima, yaitu "Tidak terdapat perbedaan yang signifikan pada kemandirian dalam menyelesaikan masalah belajar siswa kelompok kontrol pada pretest dan posttest (tanpa perlakuan layanan bimbingan kelompok)".

Tingkat kemandirian dalam menyelesaikan masalah belajar siswa kelompok kontrol yang tidak mendapat perlakuan layanan bimbingan kelompok, tidak menunjukkan perbedaan yang signifikan. Hal ini dikarenakan siswa kelompok kontrol tidak mendapat layanan bimbingan kelompok, dan kelompok ini hanya menerima layanan bimbingan dan konseling pada umumnya.

Layanan bimbingan kelompok yang diberikan pada kelompok eksperimen dikatakan belajar, karena berisikan tahapan untuk mengubah siswa kelompok eksperimen menjadi mandiri. Tidak adanya pemberian belajar kepada kelompok kontrol yang menyebabkan siswa tidak mengalami perubahan yang signifikan antara sebelum dan sesudah layanan bimbingan kelompok pada kelompok eksperimen.

Tidak adanya pembelajaran melalui layanan bimbingan kelompok membuat kelompok kontrol kurang bisa mencapai kemandirian dalam menyelesaikan masalah belajar. Sedangkan pembelajaran dimaksudkan untuk mengubah tingkah laku yang awalnya kurang baik menjadi lebih baik. Sasaran dari pembelajaran itu kepada aspek kognitif, afektif dan psikomotoriknya.

Perbedaan Kelompok Eksperimen Dan Kelompok Kontrol Tentang Kemandirian Dalam Menyelesaikan Masalah Belajar

Untuk menguji hipotesis ketiga ini digunakan teknik Kolmogorov Smirnov 2 Independent Sampels. Berdasarkan hal tersebut didapatkan hasil pengujian seperti terangkum pada tabel 3 di bawah ini: 
Tabel 3

Hasil Analisis Kolmogorov-Smirnov 2 Independent Samples Posttest : Kemandirian Siswa dalam Menyelesaikan Masalah Belajar Kelompok Eksperimen dan Kontrol Test Statistics(a)

\begin{tabular}{lr}
\hline & \multicolumn{1}{c}{ Kontrol } \\
Kolmogorov-Smirnov Z & 2,132 \\
Asymp. Sig. (2-tailed) &, 000 \\
\hline a Grouping Variable: Eksperimen &
\end{tabular}

Berdasarkan tabel 3 di atas, dapat terlihat bahwa kemandirian dalam menyelesaikan masalah belajar pada kolom Asymp.Sig. (2-tailed)/significance untuk uji dua sisi adalah 0.000, atau probabilitas di bawah $0.05(0.000<$ 0.05). Maka $\mathrm{H}_{1}$ diterima dan $\mathrm{H}_{0}$ ditolak. Ini berarti bahwa terdapat perbedaan yang signifikan pada kemandirian dalam menyelesaikan masalah belajar antara siswa kelompok kontrol dengan siswa kelompok eksperimen setelah mendapatkan perlakuan layanan bimbingan kelompok.

Hasil penelitian menunjukkan jauhnya perbedaan antara kelompok eksperimen dengan kelompok kontrol. Perbedaan antara siswa bimbingan kelompok dengan siswa kelompok eksperimen dan kelompok kontrol terdapat pada kualitas pemahaman siswa terhadap kemandirian dalam menyelesaikan masalah belajar. Artinya, siswa yang mendapat perlakuan dengan bimbingan kelompok mempunyai kemampuan yang lebih dibandingkan siswa yang tidak mendapat layanan bimbingan kelompok.

\section{KESIMPULAN DAN SARAN \\ KESIMPULAN}

Berdasarkan pembahasan di atas dapat disimpulkan :

1. Terdapat perbedaan kemandirian dalam menyelesaikan masalah belajar siswa kelompok eksperimen sebelum (pretest) dan setelah diberikan perlakuan layanan bimbingan kelompok (posttest). Siswa kelompok eksperimen yang pada pretest, kondisi kemandirian dalam menyelesaikan masalah belajarnya berada pada kategori rendah, setelah posttest naik pada kategori tinggi. Ini disebabkan adanya perlakuan layanan bimbingan kelompok kepada kelompok tersebut.

2. Tidak terdapat perbedaan kemandirian dalam menyelesaikan masalah belajar siswa kelompok kontrol pada pre-test dan post-test (tanpa perlakuan layanan bimbingan kelompok). Pada siswa kelompok kontrol, kondisi kemandirian dalam menyelesaikan masalah belajar berada pada kategori rendah (pretest), setelah posttest masih berada pada kategori rendah.

3. Terdapat perbedaan kemandirian dalam menyelesaikan masalah belajar antara siswa kelompok eksperimen yang diberikan perlakuan layanan bimbingan kelompok, dengan siswa kelompok kontrol yang tidak diberikan perlakuan layanan bimbingan kelompok.

Dari ketiga kesimpulan dalam penelitian ini terbukti bahwa layanan bimbingan kelompok bermanfaat dalam upaya meningkatkan kemandirian siswa dalam menyelesaikan masalah belajar. Pada akhirnya diharapkan dengan memiliki kemandirian dalam menyelesaikan masalah belajar yang baik, siswa dapat lebih yakin akan kemampuannya sendiri, dan dapat mengembangkan segala potensi yang ada dalam dirinya untuk belajar.

\section{SARAN}

Ada beberapa saran yang dapat penulis berikan, yaitu kepada:

1. Guru bimbingan dan konseling agar meningkatkan frekuensi penggunaan layanan bimbingan kelompok di sekolah yang disertai dengan adanya pengawasan dari pihak sekolah dan diharapkan agar guru bimbingan dan konseling mengadakan kembali bimbingan kelompok kepada siswa di sekolah yang belum mengikuti bimbingan kelompok pada saat penelitian.

2. Bagi peserta didik yang telah mengikuti layanan bimbingan kelompok yang mengalami peningkatan dalam kemandirian dalam menyelesaikan masalah belajarnya, diharapkan untuk tetap mempertahankan dan mengembangkan kemandirian teresebut. Sedangkan bagi siswa yang belum mendapatkan layanan 
bimbingan kelompok untuk mengikuti layanan yang diberikan guru bimbingan dan konseling dalam meningkatkan kemandirian dalam menyelesaikan masalah belajar.

3. Kepada kepala sekolah diharapkan untuk dapat bekerjasama dan memfasilitasi dalam membantu siswa mencapai tingkat kemandirian dalam menyelesaikan masalah belajar, sehingga siswa dapat lebih percaya diri dan mandiri dalam merencanakan dan mempersiapkan masa depannya sesuai dengan potensi, bakat dan minat yang siswa miliki.

4. Program Studi Bimbingan dan Konseling Fakultas Ilmu Pendidikan, khususnya Universitas Negeri Padang, untuk lebih meningkatkan keterampilan calon konselor/guru pembimbing di sekolah dalam melaksanakan layanan bimbingan dan konseling dengan materi kemandirian dalam menyelesaikan masalah belajar, khususnya melalui layanan bimbingan kelompok.

\section{DAFTAR PUSTAKA}

Ali, Mohammad dan Mohammad Asrori. 2008. Psikologi Remaja, Perkembangan Peserta Didik. Jakarta: Bumi Aksara.

Gibson, Robert L dan Marianne H. Mitchell. 2011. Bimbingan dan Konseling. Edisi ketujuh. Terjemahan oleh Yudi Santoso. Yogyakarta: Pustaka Pelajar.

Lesmana, Jeanette Murad. 2008. Dasar-Dasar Konseling. Jakarta: UI-Press

Ohlsen, M.M. 1977. Group Counselling. New York: Holt, Rinehart and Winston.

Prayitno. 2004. Seri Kegiatan Pendukung Konseling, L1-L9. Padang: Universitas Negeri Padang. 2009. Wawasan Profesional Konseling. Padang: Universitas Negeri Padang. . 2012. Jenis Layanan dan Kegiatan Pendukung Konseling. Padang: Universitas Negeri Padang.

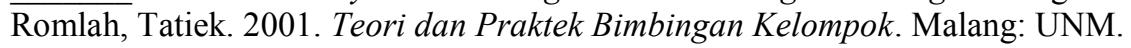

